\title{
Comparison of Transport Services in Rural Municipalities of South Bohemia
}

\author{
Petra Pártlováa ${ }^{1, *}$, and Veronika Humlerová $^{2}$ \\ ${ }^{1}$ Institute of Technology and Business in České Budějovice, Faculty of Corporate Strategy, \\ Department of Management, Okružní 517/10, 37001 České Budějovice, Czech Republic \\ ${ }^{2}$ Institute of Technology and Business in České Budějovice, Faculty of Corporate Strategy, \\ Department of Tourism and Marketing, Okružní 517/10, 37001 České Budějovice, Czech Republic
}

\begin{abstract}
Transport services and location are two of the most important key factors of regional development, especially in rural areas; in particular as in the Czech Republic, more than $90 \%$ people live in such areas. A location well related to the developing areas, population and economic activities density along the most important traffic flows seems to be the factor influencing all parts of the economical potential. It is in the rural area, where depopulation is currently occurring, however, the exposure to traffic is often neglected. The paper deals with the transport accessibility of the area according to the municipal action groups in the South Bohemian Region. The authors analyze the network of transport services in rural areas and propose measures that could be an opportunity to innovate efficiently and complete transport infrastructure in rural municipalities, including involvement of local actors.
\end{abstract}

\section{Literature review}

Rural areas in the Czech Republic and their population deal with a number of difficulties. After the post-totality reformation in 1989, there has been an increase in spatial imbalances in the distribution of population, but also to deepening the differences in socio-economic maturity of the regions [1-3]. Progressive activities, skilled labour, and human capital have increasingly concentrated in dynamically forming metropolitan areas, while rural area has been stagnant [4-5].

Many rural settlements have lost their services and facilities, reducing the frequency of public transport. The municipal infrastructure is inadequate, job opportunities are limited, and social and cultural activity is diminishing.

The outflow of younger and more educated people away from the area is a possible way how the population deals with the situation. Another possibility how to deal with the problems could be to join in activities at local and micro-regional levels. Support should therefore be given to the activation of local elites and the influx of actors from the outside [4]. If we want to deal with the problems of rural areas, i.e. to develop the area, we need to involve the factors important for the development of rural areas (generally in the

* Corresponding author: vachalova.p@seznam.cz 
development of the territory). Binek et al. [6] defines endogenous and exogenous development factors. Exogenous factories are a framework of factors and tools that influence rural development, but individual actors cannot influence them directly. On the other hand, endogenous factors are directly linked to the activities of rural users. Such factors include population migration, lack of transport service, population activity, such as the development of the region through social networking of actors. Regarding rural development, there are different forms of working together and different organization that dealing with the problems of the municipalities. The organizations include: Spolek pro obnovu venkova (the Association for Rural Reconstruction), SMO ČR (the Union of Towns and Municipalities of the Czech Republic), Národní sít' zdravých měst (the Healthy Cities of the Czech Republic), Národní observatoř venkova (National Rural Observatory) and the National Network of Local Action Groups in the Czech Republic [7-9]. Local action groups are formed in the EU under the LEADER method [7]. By Larsson [10], the original purpose of this Community initiative was to develop innovative ideas for a rural development model that would be useful in other areas too. Ray [11] describes LEADER as a program that helps the socio-economic viability of the area and supports innovative approaches to rural development at local level through the use of local resources, both physical and human. A well-working LAG, which wants to use the potential of its territory as much as possible, mainly applies the features of networking and cooperation [12-14]. It uses new approaches and procedures to guide the local development of the area [15]. Local action groups do not have the objective of generating profits, but of creating a synergy effect. LAGs are managed by people well aware of the area. They can exploit the potential of the area and the municipality.

The basic transport service is able to provide transport for all days of the week. The Czech Republic is one of the densest transport networks in Europe, especially rail and road, and in terms of density the transport infrastructure is comparable to the EU, but it lags significantly in qualitative parameters [16-17]. The same situation is in the region of South Bohemia. The transport is ensured by passenger and express trains of national and regional lines in the region and between regions and public bus lines operating in the region, and public bus lines operating on the territory of several regions [18-21]. One of the main tasks of regional or local policy in relation to transport services is undoubtedly the support of transport infrastructure. Related to this, it is necessary to note that although the current network of roads and motorway is quite dense $\mathrm{s}$ in the Czech Republic with a length of about $55,000 \mathrm{~km}$, it is largely unsatisfactory in terms of traceability, surface quality and status of objects. Similar situation is reported for the rail transport, used for transport of goods and passengers too. The Czech Republic reports a high railway network density $9,602 \mathrm{~km}$ (in 2003), but it lags behind the electrification of these lines and the number of two and multi-track lines (the operating length of these lines is $1,845 \mathrm{~km}$ ). The biggest problems include neglected technical condition and obsolete communications and security devices [17].

The authors will attempt to map the situation in the South Bohemian region based on its transport infrastructure analysis and outline several problem areas including their possible solution. They also perform a detailed analysis of grant titles from national and European sources, including both the previous programming period and current programming period of 201-2020. The paper analyses the success of the Czech Republic in submission of project applications, obtaining subsidy titles and finishing projects. It further maps new possibilities and compares proposed and achieved input, output and global indicators to the previous programming period. 


\section{Materials and Methods}

There are currently 17 LAGs in the region of South Bohemia. These 17 LAGs occupy a large part of the territory of the South Bohemian Region by their size. Similarly, this is also the case with the number of inhabitants living permanently in the territory of South Bohemian LAGs

There are 601 municipalities covering an area of $9,402 \mathrm{~km}^{2}$ in the region of South Bohemia integrated into the area of LAGs. The compare with the total, the whole region covers the area of $10,057 \mathrm{~km}^{2}$ with a total of 623 municipalities (in 2014). It means that the LAGs cover almost the whole area with the large majority of a population. The whole region has a population of 636,707 . The area covered by LAGs has a population of 455,626 . The difference does not include tows with a population of more than 25,000 .

In South Bohemia, it means that the towns of České Budějovice, Písek and Tábor are outside the area of LAGs (with a total population of 157,831 in 2014). The difference was also adjusted by deduction of the municipalities of the LAG called Krajina srdce (Landscape of my Heart) which are outside the region of South Bohemia and adding the municipalities of Jemnicko LAG in the region (a population of 23,250). This means that LAGs cover more than $90 \%$ within the South Bohemia in the area, the number of municipalities and population.

Two types of indicators were used and analysed in the paper. The first is the transport services indicator and the second is the indicator of transport accessibility.

To analyse transport services, the method by [23] was used. The aim of the evaluation is to determine the number of bus lines. The selected criteria are the distance between the closest stop (in $\mathrm{km}$ ) of individual municipalities from their catchment centres and the area of the unit. Furthermore, the time spent on the road in minutes to overcome a certain distance between the transport points. And the last pointer is the number of lines in the specified time period. The length of the line is shown in kilometres. The time period is shown is days (classified as week days, Saturdays and Sundays). The transport service uses weekdays from 6 to 20 o'clock. The resulting coefficient is as follows:

$$
\mathrm{CO}=\mathrm{di} / \mathrm{ti} * 60 * \mathrm{H} / \mathrm{hi}
$$

where:

$\mathrm{CO}$ - Coefficient of transport services

$\mathrm{Di}$ - distance (in $\mathrm{km}$ ) between the target points

ti - driving time (in min)

hi - the number of hours spent in period

$\mathrm{H}$ - the number of lines

The indicator of transport accessibility was the second indicator used in the analysis of South Bohemian LAGs and their transport services. The indicator measures the distance of the higher classes of roads and expresses the degree of transport accessibility of the municipality from other territories. The calculation was done by network analysis on motorways, expressways and roads. It takes into account different types of traffic in the Czech Republic only.

\section{Discussion}

Traffic service and its level are determined mainly by the efficiency of transport infrastructure, security, wide coverage and accessibility to all social groups. One of the 
decisive criteria for the sustainable development of the territory is its competitiveness among other territorial units.

It is possible to use several methods to analyze regions in terms of transport serviceability and to compare the achieved standard between individual regions, lower territorial units, such as micro-regions. The basic criteria for assessing transport serviceability can be the number of public transport lines (week days and weekends) and the availability of 1 st class roads and higher roads and the availability of railway stations (in kilometres).

The region of South Bohemia, following the region of Vysočina and Plzeň, is the third worse region regarding transport service. This is also due to its area of the region $(10,057$ $\mathrm{km}^{2}$ ), which is the $12.8 \%$, meaning it is the second biggest region of the Czech Republic, following the Central Bohemian Region. On the other hand, it is the fourth region regarding the population and population density (63.3 of people per $\mathrm{km}^{2}$; or even 45.3 of people per $\mathrm{km}^{2}$ if calculated with the area of LAGs only).

As shown in figure 1, there are three regions with the weakest transport service - LAG Lužnice, LAG Blatensko and LAG Třeboňsko. These sub-regions are a part of a superior region. LAG Třeboňsko with the number of bus lines on week days/ at the weekends (29/7) is a part of the region of České Budějovice. The closest LAG in the region is LAG Hlubocko -Lišovsko with the number of bus lines on week days/ at the weekends $(56 / 17)$.

LAG Lužnice with the number of bus lines on week days/ at the weekends (28/5) is a part of Tábor area. The closest LAG is Lužnicko the quite large number of bus lines on week days/ at the weekends (90/30).

The last LAG Blatensko has a low number of bus lines. It is a part of Strakonice and Písek area - LAG Strakonice with 33/4 bus lines and MAS Písecká Brána (Písek's Gate) with $34 / 6$ bus lines. Both of them have quite a poor transport service, as shown in the table. They both are peripheral regions in the South Bohemia, quite distant from the regional city of České Budějovice.

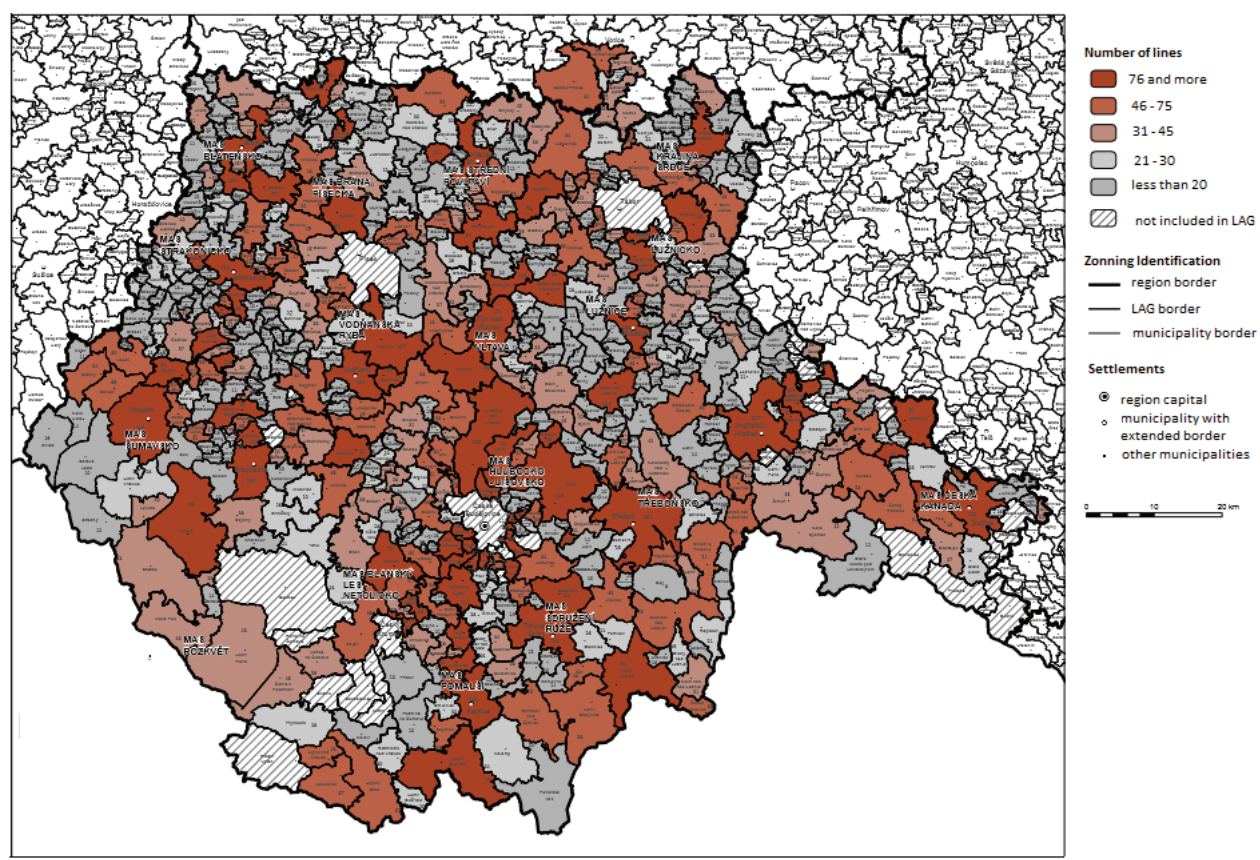

Fig. 1. Transport service in different LAGs in the region of South Bohemia (on week days). Source: authors 
Transport accessibility from other areas is the second indicator of the analysis. At first, the indicator taking different regions, with the exception of Prague, into account was analysed.

Accessibility of roads in relation to other areas is $6.4 \mathrm{~km}$. The region of South Bohemia and its LAGs are at the $7^{\text {th }}$ place compared to all the regions of the Czech Republic.The following table shows the accessibility of the area by main roads and railway stations $(\mathrm{km})$ in different LAGs of the region of South Bohemia.

If we analyse the rating of different LAGs in the region of South Bohemia, the worst accessibility is reported by the following LAGS: LAG Česká Kanada, LAG Sdružení Růže a LAG Sumava. These are border areas and it is well-known that these areas have been neglected from the point of view of road transport infrastructure. It is interesting that a bad situation is also reported by LAG Vltava. It is due to the fact, that the main roads are either in the direction to Tábor and Písek and municipalities of the Vltava LAG are right between these two regions (see figure 2).

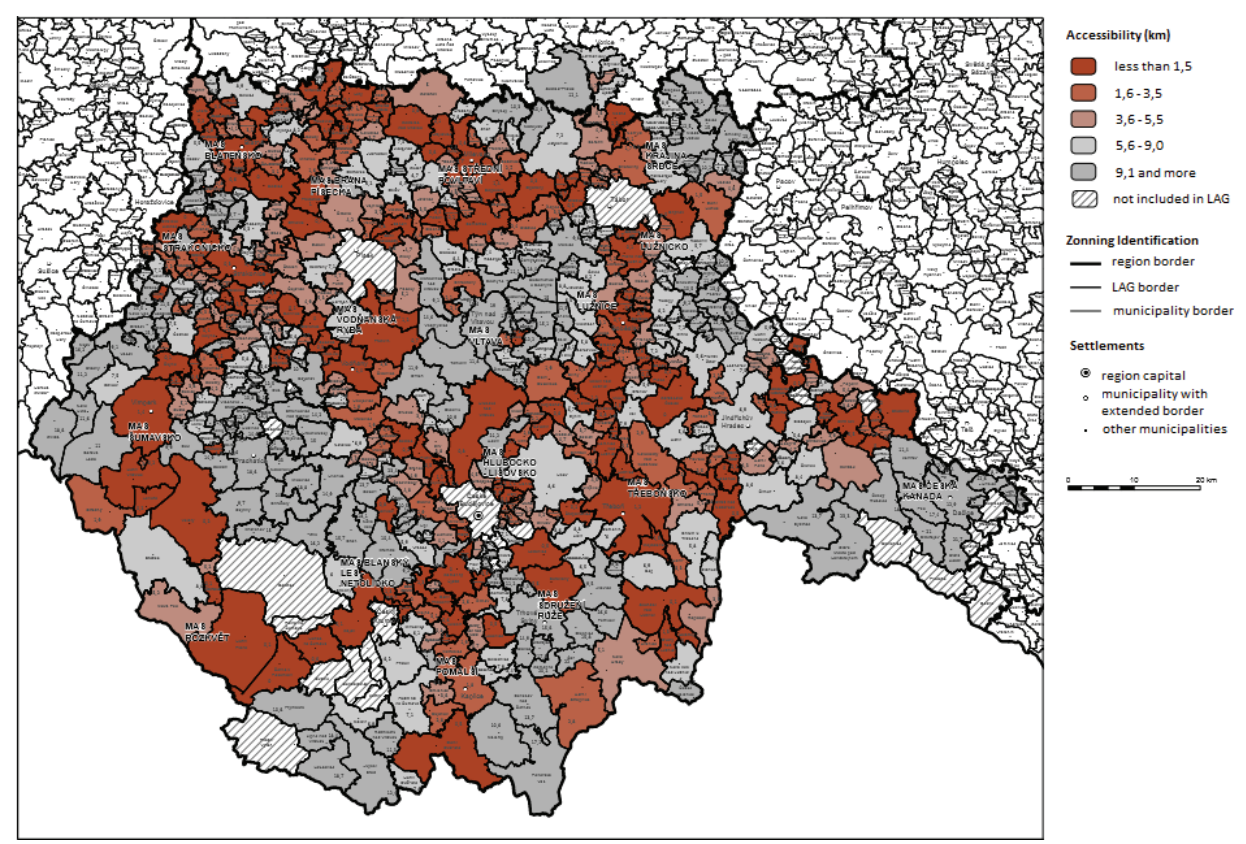

Fig. 2. Accessibility of the area by $1^{\text {st }}$ class roads and main roads and railway stations $(\mathrm{km})$ in different LAGs of the region of South Bohemia, Source: authors

Similar situation was reported to railway accessibility. In such comparison, the region of South Bohemia was the third worst; with the average distance from a municipality to a railway station of $6.3 \mathrm{~km}$. Karlovy Vary was the second best region (following Prague) with the distance of less than $4.3 \mathrm{~km}$.

Analysing different regions of the region of South Bohemia, the worst LAGs are the same as reported by road accessibility: LAG Sdružení Růže and LAG Vltava. Bad accessibility is also reported by LAGs Hlubocko-Lišovsko and Krajina Srdce. It is due to the fact, that those are neighbouring areas to České Budějovice and Tábor.

A possibility to improve the traffic infrastructure is to use grant aids. Grand aids of the European Union were chosen for a detailed analysis as their volume is larger for municipalities compared to the national budget. The municipalities in the South Bohemian region surprisingly benefited from operational programs of the programming period 2007- 
2013 in 2014 and 2015. The type of the operational program is another surprise. It could be supposed that the largest aid is received through Transport OP; however, it is not true.

Beneficiaries of subsidies from OP Transport were the state and its institutions and organizations (Správa železniční dopravní cesty - the Railway Network of the Czech Republic), trade companies and contributory organizations (̌̌editelství silnic a dálnic - the Road and Motorway Directorate), the capital city of Prague, Ministry of Transport and organizational units of the state (such as Státní fond dopravní infrastruktury - State Fund of Transport Infrastructure and Ředitelství vodních cest ČR - Directorate of Waterways of the Czech Republic).

The municipalities received transport aids from the Regional Operational Programme, and its axis 14.1. Within this axe, it was possible to receive support for the construction, modernization, repair and reconstruction of roads. In total, the ROP of the programming period in 2007-2015 supported 81 projects related to road repairs of 60 applicants in the region of South Bohemia.

Some municipalities, mostly larger towns, were multiple recipients of subsidies. The average amount for the project was 9,259 CZK per capita, with a median of 4,197 CZK per inhabitants.

The analysis does not include the towns of České Budějovice, Písek and Tábor, as they did not receive any subsidy from the ROP Jihozápad in the period. The biggest town receiving subsidies for roads from the ROP was Strakonice with a population of 23,020. The smallest village was Vrbice with a population of 57 .

As a clarification, it is necessary to notice, that not all the municipalities are owners of the roads that pass through them. It is often an organization of $\breve{R S D}$ of the Czech Republic - the Road and Motorway Directorate. As only the owner is eligible to apply and receive subsidies, the municipalities often need to wait until their road becomes a priority for R SD of the Czech Republic.

\section{Conclusion}

Although the road network in the region, with some shortcomings, the availability of municipalities and production facilities is present, its quality does not correspond to the increasing demands on the capacity and quality of passenger and freight transport.

The density of the road network in terms of the area of the area is one of the lowest in the Czech Republic, which puts great demands on maintenance and it is obvious that in many regions the quality of these roads deteriorates. That is why the priority objective was defined for this period, namely the gradual improvement of the parameters of existing roads, including relocations, bypasses of towns and municipalities, and the extension of substandard parts.

A substantial part of the border is the state border with Austria (Upper and Lower Austria) and the Federal Republic of Germany (Bavaria) with a total length of $334 \mathrm{~km}$. The cross-border nature of the region provides opportunities for effective cross-border cooperation in the area of production and services, together with strengthening social and cultural cooperation in these areas in order to avoid the negative impact of the depopulation of these areas. In these areas, the roads of the lower classes predominate. From this point of view, the South Bohemian Region has an insufficient number of quality roads across the border of the Czech Republic and it is a relatively heavy burden for the municipalities in these areas.

The level of railway transport is mostly characterized by its infrastructure and the fittings of railway rolling stocks. The structure of the railway network roughly corresponds to the needs of the region, the infrastructure does not. It significantly limits the capacity and speed of some railways, together with the rolling stock which is quite obsolete, although it 
has passed some modernization recently. Recently, the situation has improved slightly in both directions due to ongoing investments.

A detailed analysis of transport services of municipalities in the area of LAGs of the region of South Bohemia showed the following facts:

- Accessibility of remote areas and municipalities with a low population is a positive fact.

- There is at least 2/3 lines on a week day;

- There are more direct connections to the regional capital and the regional centres; compared to less stops in peripheral areas and areas outside the most important roads;

- Limited service in off-peak times on week days, due to low population in some areas;

- Absence of an integrated regional system, lack of interconnection between road and rail transport;

- Bad state of traffic communications, necessity of financing from European sources;

- Long distance to railway stations, far from settlements;

- A lack of railways, especially the absence of regional rail transport of some peripheral areas of LAG Strakonice;

- Outflow of passengers due to poor quality, the need to accelerate regional transport.

This paper is supported by the research project "From horse-drawn railway to intermodal transport" within Visegrad Fund.

\section{References}

1. J. Blažek, P. Csank, Czech Sociological Review 43, 5, 945-965 (2007)

2. J. Blažek, P. Netrdová, European Urban and Regional Studies 19, 1, $42-61$ (2012)

3. V. Jančák, T. Havlíček, P. Chromý, M. Marada, Geography 113, 3, 269-284 (2008)

4. M. Ouředníček, P. Špačková, M. Feřtrová, Czech Sociological Review 47, 4, 777-803 (2011)

5. M. Hampl, M. Marada, Geography 121, 4, 566-589 (2016)

6. J. Binek, H. Svobodová, J. Holeček, I. Galvasová, K. Chabičovská, Synergies in rural areas - Actors and rural development tools, 96 p. (Brno: GaREP Publishing, Czech Republic, 2009)

7. M. Woods, Rural (Routledge: Taylor\&Francis Book, 2011)

8. K. Gorlach, M. Lošt’ák, P. H. Money, Journal of Rural Studies 24, 2, 161-171 (2008)

9. J. Binek, I. Galvasová, H. Svobodová, K. Chabičovská, J. Holeček, Approaches to strengthen cooperation and synergies in rural micro-regions. Methodology with certificate No. 1/2012 on the recognition of applied certified methodology in accordance with the conditions of "Methodology of evaluation of research and development results", 20 p. (Brno: GaREP, spol. s r.o., Czech Republic, 2012)

10. L. Larsson, EU in the village: LEADER II, governance and rural development, In: Dargan, L., M. Shucksmith, 2008. LEADER and Innovation, Sociologia Ruralis 48, 3, 274-290 (2002)

11. C. Ray, Journal of Rural Studies 24, 422-431, (2008)

12. A. Faludi, Regional Studies 40, 6, 667-678 (2006)

13. R.D. Putnam, Journal of Democracy 6, 1, 65-78 (1995) 
14. R. Newbery, G. Bosworth, The character of rural business relations. In: Kasabov E (ed.) Rural Cooperation in Europe: In Search of the "Relational Rurals", 29-48 (UK: Palgrave Macmillan, 2014)

15. J. Coleman, American Journal of Sociology 94, 1, 95-120 (1988)

16. P. Hagget, Geography - a Global Synthesis, 833 p. (Prentice Hall: London, UK, 2001)

17. T. Hudeček, Acceptability and Impacts of its Change in the Czech Republic in the Transition Period: Relationship to the Settlement System (Dissertation work, Comenius University, Prague, Czech Republic, 2008)

18. R. Buehler, Journal of Transport Geography 19, 4, 644-657 (2011)

19. L.Ch. Baum, Journal of Urban Economics 66, 151-163 (2009)

20. M. Hampl, et. al., Journal of economics 56, 7, 696-711 (2008)

21. M. J. Dargay, Transportation Researches Part E 38, 351-366 (2002)

22. Jikord, Transport accessibility of the South Bohemian Region, Available online: http://www.jikord.cz/dopravni-obsluznost-regionu/ (2017)

23. P. Pova, Perner's contact 1 (2009)

24. Structural funds. Information about drawing subsidies, Available online: https://www.strukturalni-fondy.cz/cs/Informace-o-cerpani (2017) 